\title{
15. Yüzyılda Bir Şair ve Şârih: İlâhî ve İki Eseri*
}

\section{A Poet and Commentary in the $15^{\text {th }}$ Century: Ilâhî and His Two Works}

\author{
Büşra Kaplan ${ }^{1}$ (1)
}

*Bu makale; 2015 yılında İstanbul Üniversitesi Sosyal Bilimler Enstitüsü Türk Dili ve Edebiyatı Bölümü Eski Türk Edebiyatı Anabilim Dalı'nda, Prof. Dr. A. Azmi Bilgin danışmanlığında hazırlanan, Rûşenî-nâme: Şerh-i Ebyât-1 Rûşenî (İnceleme-Metin) başlıklı yüksek lisans tezinden üretilmiştir.

${ }^{1}$ Arş. Gör., Kırklareli Üniversitesi, Fen- Edebiyat Fakültesi, Türk Dili ve Edebiyatı Bölümü, Kırklareli, Türkiye

ORCID: B.K. 0000-0003-4854-2717

\author{
Sorumlu yazar/Corresponding author: \\ Büşra Kaplan, \\ Kırklareli Üniversitesi, Fen- Edebiyat Fakültesi, \\ Türk Dili ve Edebiyatı Bölümü, \\ Kırklareli, Türkiye \\ E-mail: busrakaplan90@hotmail.com
}

Başvuru/Submitted: 06.10.2020 Revizyon Talebi/Revision Requested: 30.10 .2020

Son Revizyon/Last Revision Received: 04.11 .2020

Kabul/Accepted: 04.11.2020

\section{Atıf/Citation:}

Kaplan, B. (2020). 15. yüzyılda bir şair ve şârih: İlâhî ve iki eseri. TUDED 60(2), 629-644. https://doi.org/10.26650/TUDED2020-806384

\section{ÖZET}

15. yüzyılda Anadolu sahası şerh edebiyatı literatüründe İlâhî mahlası kullandığı bilinen iki kişi bulunmaktadır. Bunlardan biri Abdullah İlâhî, diğeri ise Ahmed İlâhî’dir. Her ikisi de şârih ve Nakş̂̀’dir. Kaynaklarda her ikisine de atfedilen çok sayıda eser bulunmaktadır. Elimizde bulunan Rûşenî-nâme (878/1473-74) ve Müşkilgüşâ (884/1479-1480) isimli eserler de kütüphane kayıtlarına göre İlâhî mahlaslı birine atfedilmiştir. Ancak çalışmamızda ele alınacak olan bu eserler diğer bilinen İlâhî’lerin eserleri arasında geçmemektedir. Bu da farklı bir kişinin varlığını akla getirmektedir. Çalışmamızda, hayatı hakkında kaynaklarda bilgi bulunmayan bu kişinin kim olduğu eserleri üzerinden ortaya çıkarılmaya çalışılarak muhtemelen Dede Ömer Rûşenî’ye bağlı olan ya da onun yolundan giden biri olduğu sonucuna varılmıştır. Bu çalışmada, İlâhî'nin elimizde bulunan iki eserinin mensur kısımları karşılaştırılmıştır. Böylelikle her iki eserin de aynı kişiye ait olup olmadığı belirlenmeye çalışılmıştır. Bu çalışmada ele alınan eserlerin manzum kısımları da incelendiğinde mensur kısımlardaki benzerliğin bu kısımlarda da olduğu görülmüştür. Sonuç olarak; bu çalışma ile 15 . yüzyılda yaşamış olan Abdullah İlâhî ve Ahmed İlâhî dışında üçüncü bir İlâhî’nin varlığı ortaya konulmaya, Rûşent̂-nâme ile Müşkil-güşâ isimli eserlerin aynı yazara ait olduğu ve bu yazarın İlâhî olduğu ispatlanmaya çalışılmıştır.

Anahtar Kelimeler: 15. yüzy1l, İlâhî, Dede Ömer Rûşenî, Rûşenî-nâme, Müşkil-güşâ

\section{ABSTRACT}

There are two known people who used Ilâhî pseudonym in the Anatolian commentary literature of the 15th century. One of them is Abdullah Ilâhî and the other is Ahmed Ilâhî. Both are commentaries and naqxi. There are many works attributed to both in the sources. The works named Rûşenî-nâme (878/1473-74) and Müşkil-güşâ (884/14791480) that we have were also attributed to someone with Ilâhî pseudonym according to the library records. However, the works to be discussed in our study are not among the works of other known Ilâhî's. This suggests the existence of a different person. In our study, it was concluded that this person, whose life was not found in the sources, was probably someone who was attached to Dede Omer Rûşenî or who followed his path, by trying to reveal who he was by looking at his works. In this study, the prose parts of the two works of Ilâhî that we have are compared. Thus, we tried to determine whether both works belong to the same person. When the poetic parts of the works discussed in this study are also examined, it is seen that the similarity in the prose parts is also in these parts. As a result, with this study, we tried to reveal the existence of a third Ilâhî who lived in the $15^{\text {th }}$ century and who was different from Abdullah Ilâhî and Ahmed Ilâhî, to prove that the works named Rûşenî-name and Müşkil-güşâ belong to the same author and that this author is Ilâhî.

Keywords: $15^{\text {th }}$ century, Ilâhî, Dede Omer Rûşenî, Rûşenî-nâme, Müşkil-güşâa 


\section{EXTENDED ABSTRACT}

It can be seen in the $15^{\text {th }}$-century commentary literature that there are two commentators which have Ilâhî pseudonym. One of them is Abdullah Ilâhî and the other one is Ahmed Ilâhî. As a result of both of them having lived in the same period, having the same pseudonym and being commentators, their works are confused from time to time. With this study, we tried to bring together the works concerning both İlâhî's and put forward that there was another Ilâhî, who was the third one in that period. Also, evaluations will be made about his two works Rûşent-nâme and Müşkil-güşâ, in terms of being a poet and commentator.

The first part of this study is about who is Ilâhî and his works. To understand correctly all Ilâhî's, first, the focus is on the more known Ilâhî - Abdullah Ilâhî. His date of birth is not clear, but his birthplace is Simav which is in the district of Kütahya. He received his primary education there and then went to Zeyrek Madrasah which is in Istanbul. Afterwards, he went to Khorasan and Semerkant. In Semerkant he became the follower of Ubeydullah Ahrar who was the naqxi sheikh. He received permission from him and went to Bukhara. In Bukhara, he stayed next to Bahaeddin Nakşibend's tomb for a year and then went back to Samarkand. After that, his hodja sent him to Simay,Anatolia, with the guiding mission. When he was in Simav, Fatih Sultan Mehmed Han invited him to Istanbul. He went to Zeyrek in İstanbul, and guided people around. After that, he went to Vardaryenicesi and died there in 896/1491 (Kara, 1988, s. 1-4). When looking at the sources, it can be seen that researchers do not agree with each other on the acceptance of Fatih's invitation. Some researchers claim that he accepted the invitation, others disagree.

The other Ilâhî - Ahmed Ilâhî was from Bukhara. His date of birth is not clear. Naqxi, melami and halveti commentator, he stayed in seclusion in a dervish lodge in Halab. In Fatih's period, he came to Yogurtlu Baba Dergâhı in Bursa and guided people around. Fatih invited him to İstanbul too. He accepted and went there. When he died is also uncertain. He is buried in the hazire of the Islamic monastery built by Derterdar Derviş Efendi (İlâhî, 2015, s. 12-13).

Both Ilâhî's have lots of works which are discussed largely in this study. According to a general view, it can be said that possible works of Abdullah Ilâhî are Şerh-i Vâridât-ı Kübrâ Lişeyh Bedreddin Simavî or Keşfu'l Varidat li Talibi'l Kemâlât ve Gâyetü'd-Derecât, Meslekü 't Tâlibîn ve'l-Vâsilîn, Esrâr-nâme and Zâd ül Müştakîn; posible works of Ahmed İlâhî are Dîvân, Tasavvuf-nâme, Şerh-i Miftahu'l Gayb and Şerh-i Istılahât-ı Miftahu'l-Gayb.

In addition to the two mentioned above, there is one more Ilâhî in that period. His existence

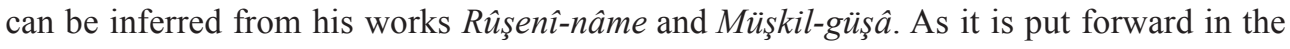
study, there are no works of other Ilâhî's called R̂िşenî-nâme and Müşkil-güşâ. In the sources no information about him can be found. The only way to recognize him is by looking at his works. When looking at his works it can be seen that he uses certain expressions about Dede Omer Rûşenî. Also, he named one of his works R̂uşenti-nâme. 
Ilâhî's first works name is R̂िşent-nâme of which there are two copies in the libraries. One of them, which is dated 878 (1473-74), is in the Süleymaniye Library under the Reşid Efendi section with numbered 390. The other one is in the National Library under the Yazmalar section and numbered Yz A 637-3. The second work of Ilâhî is Müşkil-güşâ, which is dated 884 (1479-1480), can be found in Manisa State Public Library and numbered 2955/6. Both of his works are about a commentary about two poems of Dede Omer. With these works, he became the first Turkish commentator of a Turkish poem and Rûşent-nâme became the first Turkish commentary made about a Turkish poetry.

In this study, these two works of Ilâhî are compared with each other by focusing on the prose and verse parts of them separately and it is concluded that Ilâhî's commentary methods and the literary arts which he uses in his works are parallel to each other. He uses citations, references, rhymed prose, paronomasia, contradictions and derivations in his works.

In his works Ilâhî uses verses beside prose to explain himself in a catchier way. Technically, he uses mathnawi form and short meters with didactic language successfully. Also, in addition to citations, references, similes, metaphors, contradictions and paronomasia, he uses inlays, repititions and laff $\mathrm{u}$ nashr in his verses.

To sum up, Ilâhî who is a poet commentator of the $15^{\text {th }}$ century, has two works, which are Rûşent-nâme and Müşkil-güşâ. He might have been a follower of Dede Omer or a person who had ties of affection to Dede Omer. He is the first Turkish commentator of a Turkish poem and his works are the first Turkish commentaries made regarding Turkish poetry. 


\section{GİRIŞ}

15. yüzyıl Anadolu sahası şerh edebiyatı literatürüne bakıldığında, kaynaklarda İlâhî mahlaslı iki kişinin zikredildiği görülür. Bunlardan ilki Abdullah İlâhî, ikincisi ise Ahmed İlâhî’ dir. Her ikisinin de yaşadığı dönemin aynı olması, aynı lakabı kullanması ve şârih olması eserlerinin birbirine karıştırılmasına sebep olmuştur. Bu çalışma ile hem her iki İlâhî hakkında yapılan araştırmalar bir araya getirilmeye çalışılacak hem de aynı dönemde yaşayan üçüncü bir İlâhî'nin varlığı ortaya konulmaya çalışılacaktır. Buna ek olarak, elimizde R̂ิşent̂-nâme ve Müşkil-güşâ adını verdiği iki eseri bulunan bu İlâhî’nin, şârihliği ve şairliği hakkında değerlendirmelerde bulunulacaktır.

\section{1. İlâhî Mahlaslı Şârihler}

Elimizdeki kaynaklara göre, daha çok bilinen İlâhî mahlaslı şârih Abdullah İlâhî’ dir. Doğum tarihi bilinmemekle beraber bugün Kütahya'ya bağlı olan Simav'da dünyaya gelmiştir. İlk öğrenimini orda gördükten sonra İstanbul' daki Zeyrek Medresesine devam etmiştir. Ardından Horasan'a daha sonra da Semerkant'a gitmiştir. Semerkant'ta Nakşîbendî şeyhi Ubeydullah Ahrar'ın müridi olmuştur. Ondan icazetini aldıktan sonra Buhara'da Bahaeddin Nakşibend'in kabrinin yanında bir yıl geçirerek Semerkant'a dönmüştür. Daha sonra hocası onu irşat vazifesi ile Anadolu'ya, Simav'a geri göndermiştir (Kara, 1988, s. 1).

Simav'da irşada devam eden İlâhî'yi Fatih Sultan Mehmed Han İstanbul'a davet etmiştir. Ancak bu daveti kabul edip etmediği ile ilgili kaynaklardaki bilgiler çelişkilidir. İlâhî ile ilgili ilk araştırmacı konumundaki Ertaylan İlâhî’nin 874/1469-1470 yılında yani Fatih'in vefatı öncesinde İstanbul'a geldiği görüşündedir (Ertaylan'dan naklen Özçelik, 1990, s. 18-19). ${ }^{1}$ Kasım Kufralı, İlâhî'nin Fatih'in vefatından sonra İstanbul'a gittiğini kabul ederken² (Kufralı, 1949, s. 131-132) eldeki bilgileri değerlendirmeye tabi tutan Mustafa Kara, İlâhî’nin bu davete icabet etmediğinin ya da icabeti geciktirdiği dolayısıyla Fatih ile görüşmeme ihtimalinin daha kuvvetli olduğu kanaatine varılacağını söylemektedir (Kara, 1988, s. 2-3). Biz ise Ertaylan'ın konuyla ilgili ilk araştırmacı olması ve araştırma yaptığı dönemde eldeki bilgilerin sınırlı olması sebebiyle, Kara'nın işaret ettiği üzere onun bahsettiği İlâhî’nin Ahmed İlâhî olduğu ve dolayısıyla onun çalışması üzerinden Abdullah İlâhî ile ilgili bir yargıya varılamayacağı kanaatindeyiz. Diğer bir deyişle, Abdullah İlâhî'nin Fatih'in vefatından sonra İstanbul'a gitmiş olması akla daha yatkın görünmektedir. İstanbul'da Zeyrek civarında irşada devam eden İlâhî daha sonra Vardaryenicesi'ne yerleşmiş ve 896/1491 y1lında orada vefat etmiştir (Kara, 1988, s. 4). ${ }^{3}$

1 Mustafa Kara, Ertaylan'ın çalıştığı İlâhî’nin Abdullah değil Ahmed İlâhî olduğu görüşündedir (Kara, 1988). Aşağıda açıklanacağı üzere Ahmed İlâhî’nin Fatih ile görüştüğü bilindiğine göre Kara'nın görüşü isabetli görünmektedir.

2 Abdullah İlâhî ile ilgili yüksek lisans tezi hazırlayan Özçelik de onun Fatih'in vefatı sonrası İstanbul'a gittiğini kabul etmektedir (Özçelik, 1990, s. 10).

3 Abdullah İlâhî için ayrıca bakınız: (Kara \& Algar, 1988). 
İlâhî’nin eserleri araştırıldığında ise yine kaynaklarda farklı sayılarda ve isimlerde eserlerinin olduğu görülür. Ertaylan İlâhî’ye Şerh-i Vâridât-ı Kübrâ li-Şeyh Bedreddin Simavî, Zâdü'lMüştakîn, Necâtü'l-Ervâh min Denesi'l-Eşbâh, Esrâr-nâme, Meslekü't-Tâlibîn, Manzûme-i Mîraciye, Füsûlü'l-Vüsûl, Cevâhir-i Irfan, Risâle-i Hizrlyye, Necâtü'l-Kulûb li-Tâlibi'l Matlûb ve Divan-ı Illâhî adlı eserleri atfeder. Kaynaklarda geçen Şerh alâ Miftâhi'l-Gayb li-Şeyh Sadreddin isimli eserin de Ahmed İlâhî'ye ait olabileceğini kaydeder (Ertaylan'dan naklen Özçelik, 1990, s. 24).

Kara ise Ertaylan'ın Şerh-i Vâridât-ı Kübrâ li-Şeyh Bedreddin Simavî adıyla kaydettiği eserin adının Keşfu'l-Varidat li-Talibi'l Kemâlât ve Gâyetü'd-Derecât olduğunu, Meslekü 'tTâlibîn adıyla kaydedilen eserin adının Meslekü't-Tâlibîn ve'l-Vâsilîn olduğunu söyler. Ayrıca, Esrar-nâme, Zâdu'l-Muştakîn, Risâle-i Tasavvuf, Risâle-i Vücûd, Risâle-i Ehadiye, Risâle-i Es'ile ve Ecvibe adlı eserlerin Abdullah İlâhî'ye ait olduğunu söyler. Kaynaklarda Futuhât-l Ilâĥे'nin de ona atfedildiğini ancak başka bir şairin olabileceğini, ayrıca Kenzu'l-Esrar diye bir eserin de ona atfedildiğini ama böyle bir risalenin bilinmediğini dolayısıyla müellifinin de İlâhî olamayacağını belirtir (Kara, 1988, s. 375-377).

Mustafa Kara, daha sonra Hamid Algar ile bir çalışma yayımlar (Kara \& Algar, 1988). Bu çalışmada yukarıda bahsedilen eserlerden Risâle-i Tasavvuf, Futuhât-ı İlâhî ve Kenzu'l-Esrâr eserlerini çıkarırlar, Menâzilü'l-Kulûb'u eklerler (Kara \& Algar, 1988, s. 111-112). Kenzü'lEsrâr' in İlâhî'ye nisbet edildiğini belirtirler. Necâtü'l-Ervâh veya Risâle-i Molla İlâhî veya Risâle-i Es'ile ve Ecvibe isimleriyle bilinen eserin Abdullah İlâhî'nin çağdaşı olan Ahmed İlâhî'ye ait olması ihtimalinin daha yüksek olduğunu ileri sürerler. Mi'râciyye adlı eserin de ona atfedildiğini ama eserin elimizde bulunmadığını ayrıca Ertaylan'ın ortaya koyduğu Dîvân'ın da Abdullah İlâhî'ye aitliğinin kesin olmadığını belirtirler (Kara \& Algar, Abdullah-1 İlâhî, 1988, s. 112).

Özçelik ise İlâhî hakkında çalışma yapanları ve çalışmaları özetleyerek bütün kaynaklarda Necâtü'l-Kulûb li-Tâlibi'l-Matlûb ve Meslekü 't-Tâlibîn'in kesin olarak Abdullah İlâhî'nin eserleri olarak kabul edildiğini söylemekle yetinir (Özçelik, 1990, s. 26). Abdullah İlâhî’nin çağdaşı olup şârih olan diğer İlâhî ise Ahmed İlâhî'dir. Doğum tarihi bilinmemekle beraber Buharalı olduğu bilinen İlâhı̂’nin Anadolu'ya gelmeden önceki hayatı hakkında elimizde yeterli bilgi yoktur. Nakşibendiyye, Melamiyye ve Halvetiyye olan şârih Halep’te Necmeddin Kübra'nın takipçilerinden Şeyh Necîb'in tekkesinde bir süre halvet hayatı yaşamıştır. Fatih döneminde, Bursa' da Yoğurtlu Baba Dergâhı'nda irşada başlamıştır. Fatih tıpkı Abdullah İlâhî gibi onu da İstanbul'a davet etmiştir. O da davete icabet ederek İstanbul'a gidip orda irşat faaliyetlerine devam etmiştir. Ölüm tarihi belirsiz olan İlâhî, kendisi için Defterdar Derviş Efendi tarafından yaptırılan dergâhın haziresine defnedilmiştir (İlâhî, 2015, s. 12-13). ${ }^{5}$

4 Çalışmamızda verilen eser isimlerinin imlasında; kullanılan kaynaklardaki imlalar, izafet kurallarına uygun olarak düzenlenmiştir.

5 Hayatı hakkında bilgiler içeren diğer çalışmalar için ayrıca bakınız: (Kuru, 2014), (Yıldırım, 2014), (Tek, 2006), (Ördek, 2020). 
Ahmed İlâhî'nin eserlerinden birinin Dîvân'1 olduğu söylenebilir. Ertaylan, bu eseri Abdullah İlâhî'ye atfederek yayımlamıştır. Ancak, Miftâhü'l-Gayb şerhinin Ahmed İlâhî’ye ait olabileceğini ve böyle bir durumda yayımladığı eserin de Ahmed ilâhî'ye ait olacağını belirtmiştir (Ertaylan'dan naklen Özçelik, 1990, s. 25). Daha sonra Ertaylan'ın yayımladığı bu eserin Ahmed İlâhî'ye ait olduğu Kara tarafından ortaya konulmuştur (Kara, 1988). Çalışmasında, Cemal Kurnaz da aynı savı desteklemiştir (Kurnaz, 1996) ve o eserdeki Türkçe şiirlere ek başka Türkçe şiirler ortaya koymuştur. Kurnaz, bu çalışmasında İlâhî’ye ait olduğu kesinleşen üç eserin olduğunu belirtir: Dîvân, Şerh alâ Miftâhi'l-Gayb, Risâle-i Es 'ile ve Ecvibe (Kurnaz, 1996, s. 169-170) Esra Kuru ise 2014 y1lında Ahmed İlâhî’ye ait olduğunu belirttiği Pendnâme' yi yayımlar (Kuru, 2014). Ancak çalışmasında herhangi bir müellif kaydı olmadığını ve metinde de herhangi bir ipucu bulunmadığını belirtir. Kuru, şu eserleri Ahmed İlâhî’ye nisbet eder: Tercüme-i Miftâhu'l-Gayb, Şakâyiku'l-Hakâyık li-Sultâni'l-Hakâyık, Dîvân, Hızır-nâme, Kenzü'l-Esrâr, Risâle-i Es 'ile ve Ecvibe, Şerh-i Ba'zı Rubâiyyât-ı Ömer Hayyam, Merâtib-i Fakr, Sırr-ı Tâcü'l-Emcâd, Mîzânü'l-Efkâr, Mahzenü'l-Cevâhir fì-Esrâr-ı Zikr, Risale-i Tevhîdiyye, Tasavvuf Risalesi ve Pend-nâme (Kuru, 2014, s. 774-775).

Aynı yıl yayım yapan İsmail Yıldırım ise (Yıldırım, 2014) Kuru ile aynı eserleri Ahmed İlâhî'ye atfeder ancak sadece bir eserde ayrılır. Kuru, Risâle-i Es'ile ve Ecvibe ile Tasavvuf Risalesi'ni ayrı eserler olarak alırken Yıldırım aynı eser olarak ele almıştır (Yıldırım, 2014, s. 575-576). Bu çalışmalardan sonra 2015 yılında Mücahit Kaçar ve Ahmet Akdağ Tasavvufnâme isimli eseri kitap olarak yayımlarlar. Araştırmacılar eserin ön kısmında Ahmed İlâhî’nin kim olduğunu ve eserin müellifi olup olamayacağını tartıştıktan sonra, eserin müellifinin Ahmed İlâhî olduğu sonucuna varırlar. Tasavvuf-nâme, Dîvân, Şerh-i Miftahu'l-Gayb ve Şerh-i Istılahât-ı Miftahu'l-Gayb adlı eserlerin Ahmed İlâhî'ye ait olduğunu ortaya koyup Yıldırım'ın ona atfettiği eserleri de ayrıca belirtmişlerdir. Hem Ahmed İlâhî hem de Abdullah İlâhî ile ilgili çalışmalarda Risâle-i Tasavvuf, Risâle-i Es 'ile ve Ecvibe, Necâtü'l-Ervâh, Risâle-i Mollâ İlâhî, Hızır-nâme, Müntehabât-ı Mollâ İlâhî, Risâle-i Hızriyye, Makalât-ı Mollâ İlâhî başl1klarıyla ayrı ayrı ya da kısmen bir arada olan çalışmaların hepsinin Tasavvuf-nâme adlı eserin farklı başlıklı nüshaları olduğunu ortaya koymuşlardır (İlâhî, 2015, s. 14-19).

Yapılan çalışmalar neticesinde son durumda araştırmacıların Abdullah İlâhî’ye ait olduğu konusunda büyük oranda hemfikir olduğu eserler şunlardır: Şerh-i Vâridât-ı Kübrâ li-Şeyh Bedreddin Simavî ya da Keşfu'l Varidat li Talibi'l Kemâlât ve Gâyetü'd-Derecât, Meslekü't Tâlibîn ve'l-Vâsilîn, Esrâr-nâme ve Zâdü'l-Müştakîn. Ahmed İlâhî'ye ait olduğu konusunda büyük oranda hemfikir olunan eserler de şunlardır: Dîvân, Tasavvuf-nâme, Şerh-i Miftahu'l Gayb ve Şerh-i Istılahât-ı Miftahu'l-Gayb.

\section{Dede Ömer Rûşenî Şârihi İlâhî ve Eserleri}

Yukarıda ayrıntılı olarak bahsettiğimiz iki İlâhî’ye ek olarak biz bu dönemde yaşamış bir diğer İlâhî daha olduğunu düşünmekteyiz. Kaynaklarda yukarıda bahsedilen İlâhî'ler dışında bir İlâhî bulunmadığından hayatı hakkında bilgi sahibi olunamasa da onun eserlerinden 
kim olduğuna dair ipuçları yakalanabilmektedir. Söz konusu İlâhî’nin elimizde iki eseri bulunmaktadır. Eserlerinden birinde, Dede Ömer Rûşenî’nin bir tercî-i bendini' diğerinde ise bir gazelini ${ }^{7}$ şerh etmiştir. Rûşenî'nin bir gazelini şerh ettiği ve adını Ŗ̂̂şent̂-nâme koyduğu eserin ilk varağında müellif kendisini hakir, fakir ve bende olarak andıktan sonra "Rûşenînün eşiginün itiyem” ifadesini kullanmaktadır. Metnin telif sebebini de Rûşenî’nin ona işaret etmesine bağlamaktadır. Ayrıca Rûşenî için metninde;

"Rûşenîdür zulmetde kalanlarun rehberi",

"Yolımı itgil tarîk-i Rûşenî"

"Ayurma velîk Rûşenîden",

"Rûşenînün hazretine lâyık it",

gibi ifadeleri kullanması ve esere Rûşenî’nin adını vermesi, onun Rûşenî’ye son derece bağlı olduğunu göstermektedir. Bu açıdan İlâhî, Rûşenî’nin bir müridi ya da takipçisi ve Rûşeniyye tarikatına bağlı biri olabileceğini düşündürmektedir (Kaplan, 2015, s. 17-18).

Abdullah İlâhî ve Ahmed İlâhî, Nakşî’ dir. İlâhî ise Rûşenî olduğunu düşündürdüğünden tarikat açısından onlardan ayrılmaktadır. Ayrıca Nakşibendîlik ile Rûşenîliğin çok yakından ilgili olmaması da (Vicdani, 1995, s. 189-199) farklı bir İlâhî’nin varlığını doğrular niteliktedir. Nitekim o dönemde birinin bağlı olduğu tarikatın dışındaki bir şeyh hakkında bu tarz ifadelerde bulunması ve ona olan bağlılığını bildirmesi çok düşük bir ihtimaldir (Kaplan, 2015, s. 18).

İlâhî'nin ilk eseri R̂̉şen̂̀-nâme'dir. Bu eser, Mevlâna Dede Ömer Rûşenî'nin Divan'ında 26. sırada bulunan 5+5 duraklı 10'lu hece ölçüsüyle yazılan yedi beyitlik “olmaz" redifli şiirin (Tavukçu, 2005, s. 140) şerhidir. Bu eser birbirini yer yer tamamlayan, yer yer de birbirini takip eden; kütüphane kataloglarında farklı adlarda kayıtlı bulunan iki nüshadan oluşmaktadır (Kaplan, 2015, s. 19-21). Metnin nüshalarından biri Şeyh İlâhî Abdullah adına Şerh-i Ebyat-i Ömer Rûşenî başlığıyla Süleymaniye Kütüphanesi (Reşid Efendi, nr. 390)'nde kayıtlıdır. Tamamı dört bölümden oluşan bir kitabın son bölümünü teşkil eden eser 88 ilâ 111. varaklar arasında yer almaktadır. Her varakta ortalama 13 satır bulunmaktadır. Eserin yaprakları filigranlı orta inceliktedir. Aharlı kâğıda talik yazıyla yazılmıştır. Yapraklarda dikey su yolu vardır. Eserin dış boyutları ortalama 158-108 mm., iç boyutları ise ortalama 110-73 mm.'dir (Kaplan, 2015, s. 44).

Diğer nüshası ise Rûşenî Ömer Dede adına Eş'âr başlığıyla Ankara'da Milli Kütüphane (Yazmalar, nr. Yz A 637-3)'de kayıtlıdır. Üç bölümlü bir kitabın son bölümü olan eser 73 ilâ 91. varaklar arasında bulunmaktadır. Eserde silinmiş ve yıpranmış kısımlar ile kurt yenikleri mevcuttur. Eserin sırtı kirlenmiş beyaz bezle onarılmış durumdadır. Kapakları silinmiş ebru kâğıt ile kaplıdır. Sertabı ve kapak kenarları kahverengi meşindir. Ancak yer yer dökülmüş

6 Bu eser hem yüksek lisan tezi olarak hazırlanmış (Ateş, 2017), hem de kitap olarak yayımlanmıştır (Uyan, 2016).

7 Bu eser yüksek lisans tezi olarak hazırlanmıştır (Kaplan, 2015). Çalışmamızda bu tezdeki transkripsiyonlu metin esas alınmış olup transkripsiyon harfleri gösterilmemiştir. 
durumdadır. Mıklepli ancak harap, mukavva bir cilde sahiptir. Eserin başı eksik, söz başları, duracaklar kırmızı ve yapraklar nem lekelidir. Ayrıca eserin şiraze kısmı bozuktur. Yapraklarda su yolu vardır, filigran yoktur, yer yer onarım görmüştür. Bazı yapraklar kopuktur. Her varağında ortalama 19 satır bulunan eser bozuk talik hattıyla abadi türü bir kâğıda yazılmıştır. Eserin dış boyutları ortalama 218-130 mm., iç boyutları ise ortalama 165-88 mm.'dir. Eserin telif tarihi 878 (1473-74) y1lı olarak belirtilmiştir (Kaplan, 2015, s. 45).

İlâhî’nin ikinci eseri Müşkil-güşâa' dır. ${ }^{8}$ Bu eser Mevlâna Dede Ömer Rûşenî’nin Divan'ında musammatlar kısmında "Fi't-terkîb bi-tarîkı'r-rumûz" başlığıyla 4. sırada bulunan şiirin (Tavukçu, 2005, s. 207-210) şerhidir. Bu eser tek nüshadır ve bu nüsha Manisa İl Halk Kütüphanesi (2955/6)'nde kayıtlıdır. Altı eserlik bir mecmuanın son kısmında yer almaktadır. 114 ila 152 'nci varaklar arasındadır. Varaktan varağa değişmekle beraber her varakta ortalama 17 satır bulunan eser, saykallı âbâdî bir kâğıda nestalik hattıyla yazılmıştır. Eserin kenarları ve sırtı siyah, köşeleri ve sertabı vişne rengi, duracaklar kırmızı, meşin desenlidir. Kâğıt kaplı, mukavva ciltli, mıklepli, yaprakları kurt yeniklidir. Eserin dış boyutu ortalama 175-145 mm., iç boyutu ise ortalama 125-97 mm.' dir. Eserin telif tarihi 884 (1479-1480) yılı olarak belirtilmiştir (Ateş, 2017, s. 2-3; Uyan, 2016, s. 19).

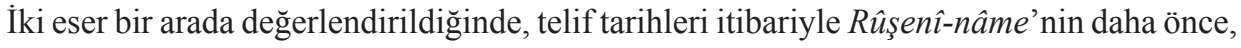
Müşkil-güşâ'nın ise daha sonra yazıldığı görülmektedir. Bu bakımdan Uyan'ın 2016 yılında “Anadolu Sahasındaki İlk 'Türkçe Şiir' Şerhi” üst başlığı ile yayımladığı Müşkil-güşâ adlı eser (Uyan, 2016), Anadolu sahasındaki ilk değil ikinci "Türkçe şiir” şerhi konumundadır. Eserleri Anadolu sahasındaki ilk Türkçe şiir şerhleri kapsamında olan İlâhî de Anadolu'daki ilk Türkçe şiir şârihi konumundadır. ${ }^{9}$

\section{3. İlâhî’nin Şârihliği}

İlâhî, her iki eserinde de şerh metnini hem manzum hem mensur olarak oluşturmuştur. Eserlerinin mensur kısımlarında genel itibariyle önce ele alınacak olan beyti verir. Daha sonra beytin durumuna göre kelimeleri ya da kelime gruplarını ele alıp "ya'nî" diyerek ya da "murâd" diyerek onların açıklamalarını yapar. Kelimelerle ilgili gramer açısından yoğun açıklamalara girişmez. Kelime ve kelime gruplarını açıkladıktan sonra cümle düzeyinde de beytin anlamını açıklar. Tüm bu açıklamaları yaparken sözlerini doğrulamak için çeşitli iktibaslar yapar, telmihlerden faydalanır. Hadislerden, ayetlerden, çeşitli şairlerin şiirlerinden ve deyimlerden faydalanır. Bunları belli bir sıralama ile vermekten ziyade metnin bütünlüğünü bozmayacak bir biçimde yerine göre kullanır. İktibaslar dışında aşağıda da değinileceği üzere, açıklamalarında

8 Çalışmamızda bu eseri ortaya koyan Canan Ateş'in transkripsiyonlu metni (Ateş, 2017) esas alınmış olup transkripsiyon harfleri gösterilmemiştir.

9 Türk edebiyatında ilk şerhin ne olduğu hususu hangi açıdan bakıldığına bağlı olarak değişmektedir. Elimizdeki eserler, Anadolu sahasında Rûşenî'nin Türkçe yazmış olduğu şiirlere yapılmış Türkçe şerhlerdir. Bu bakımdan kaynaklarda verilen bilgilere göre bu özelliklere sahip olan en eski tarihli şerh 1497 tarihli Şeyhzâde’ye ait Şerh-i Gazel-i Yûnus Emre isimli eserdir (Ceylan, 2007, s.18). İlâhî’nin eserlerinin 1473-74 ve 1479-1480 tarihli olmaları onları ilk şerhler konumuna yükseltmektedir. 
ilgili gördüğü yerlerde kullandığı İlâhî mahlası vesilesiyle kendi yazdığı anlaşılan mesnevi nazım şekliyle kaleme alınmış şiir parçalarını da metne ekler. ${ }^{10}$

Rûşent̂-nâme' den ve Müşkil-güşấ' dan alınan aşağıdaki parçalar, şârihin tüm şerh boyunca uyguladığg ve yukarıda açıklanmaya çalışılan yaklaşımının en kısa halini teşkil eden birer örnektir:

"Beyt-i çehârom

Aç gözün sûfî̀ iç mey-i sâfı

Zühdi koy dime mey mubâh olmaz

Dinle yine ey tâlib-i râgıb ve ey ehl-i 'ş̧ka musâhib! Dördünci beytün ma'nisini erişdüre murâda seni ki "aç gözün sûfî” işâretdür basîret-i kalbe ya'nî gönül gözine ve yaluguz sûfîye mahsûs degül bu hitâb belki 'âmdur cümle tâliblere ya'nî; aç gönül gözini gör andan mahbûb yüzini yine anunla bu sözün yüzini ki basîret-i kalb açılmasa ve anun yüzindeki gubâr saçılmasa câm-1 cihân-nümâ olmaz ve âyine-i kibriyâ olmaz pes her tâlibe lâzımdur ki cidd [ü] cehd eyleye ve zikr [ü] fikre meşgûl ola, tâ meftûh ola 'aynı ve merfû' ola şems-i rûhun 'aynı ki hadîs-i Resûldür 'aleyhisselâm “ذاذا احبالله عبدا فتح عليه باب قلبه 'ya’nî her gâh ki Hak bir kulın sevse açar basîretini ve içirür câm-1 hakîkatini tâ tecellî-yi nûrına lâyık ola ve gaflet meyinden ay1k ve ana tecellî eyleye nûr-1 likâ olur; mesel " "و حر موسى صعقى" pes "aç gözün sûfî" emrdür pîr-i mürşid cânibinden, mürîd-i sâhib-i irâdete, ki tâlibdür genc-i sa'âdete, "iç mey-i sâfı" ya'nî çün basîret-i kalb-i sâhib-i 'ayn oldı ve küdûretden safâ buldı ve san'at-1 beşeriyyeden sâf u musaffâ "iç mey-i sâfi” ki murâd "mey-i sâfî”'den zülâl-i hayât-1 ma'rifetdür şarâb-1 nâb- 1 hakîkat,

Şi'ir

İçmeyince câm-1 ma'nîden şarâb

Olmayınca mest-i medhûş-1 harâb

Açmayinca dîdesinden perdesin

Cân içinde görmeye perverdesin” (Kaplan, 2015, s. 75-76)

"Mine't-tercî'

Re's-i kelb üstine kılıcı namâz

Cerv ile eylemeyüp ikrâhı

“Re's-i kelb” lügat-i müşterekdür, bildireyüm ana kim gerekdür. Zâhiren bir ma’nîsi ey ehl-i me’âlî, “علم لعلم عالى" ya’nî uca daga 'Arab dilince re's-i kelb dirlermiş ve murâd andan niyet-i a'lâ vü himmet-i vâlâdur. Zîrâ ki riyâzet ü ibâdetlerinde ve Hakka tâ'at ü itâ'atlerinde niyyet-i hâlisleri “li-vechi'llâh"dur. Bilür bu vechi ol kim âgâhdur ya'nî ümîd-i cennet ü bîm-i dûzahdan degül, çün Hakka sıdk ile

10 İlâhı̂’nin şerh metodu ile ilgili değerlendirmeler için bakınız: (Kaplan, 2015, s. 7), (Ateş, 2017, s. 20-22) ve (Uyan, 2016, s. 27-28). 
baglamışlardur gönül. Anunçün Hazret-i Seyyid-i Kâinât ve hulâsa-i mevcûdât Muhammed Mustafa ‘aleyhi's-salâtü ve's-selâm bu hadîsi söyleyüpdür ve niyyet-i

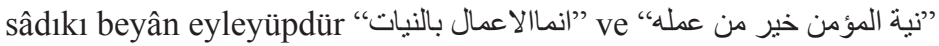

\section{Nazm}

Ya'nî 'amelde bûy-i riyâ vardur ey âhî

Niyyetse yoh durur bu sana söylerüm dahi

Çün Hakdan özge niyyetüne gelmedi senün

Kurbet bisât üzre ola cây ü meskenün” (Ateş, 2017, s. 33-34)

Görüldüğü üzere her iki örnekte de şârih önce ilgili beyti "beyt-i çehârom" ve "mine’t-terci" " diyerek verdikten sonra okurunu da işin içine katarak beyitteki kelime ve kelime gruplarını açıklamıştır. Her ikisinde de söylediklerine delil olarak hadislerden iktibas yapmıştır. Daha sonra ise söylediklerini bir de manzum olarak ifade etmiştir. Dili itibariyle metnini halka yönelik yazmış olduğu söylenebilen İlâhî, metnini tasavvufi bir yaklaşımla kaleme almıştır.

Kullanılan şerh metoduna ek olarak İlâhî’nin şârihliğinin önemli bir özelliği de secili bir dile sahip olmasıdır. Bu açıdan Rûşent̂-nâme'den alıntıladığımız yukarıdaki metinde; "râgıbmusâhib", "tâlîb-râgıb", "gözini-yüzini”, "oldı-buldı" kelimeleri arasında mutarraf seci; "zikrfikr", "basîret-hakîkat" kelimeleri arasında mütevâzî seci bulunmaktadır. Müşkil-güşầ'dan alıntıladığımız yukarıdaki metinde; "müşterek-gerek", "tâ'at-itâ'at", "kâinât-mevcûdât", "degül-gönül”, "söyleyüpdür-eyleyüpdür" kelimeleri arasında mutarraf seci; "riyâzât-ibâdet" kelimeleri arasında mütevâzî seci bulunmaktadır.

İlâhî, mutarraf ve mütevâzî seciye ek olarak murassa seci de kullanmıştır. R̂uşenî-nâme' den alıntıladığımız aşağıdaki metinde "fakîr-i za'îfe-nahif-i lehîfe" kelime gruplarında ve Müşkilgüşâ' dan alıntıladığımız aşağıdaki metinde "şerî'at-şi’âr, tarîkat-disâr, hakîkat-âsâr" ve "mihr-i burc-1 ma'rifetden - mühr-i dürc-i meskenetden" kelime grupları arasında murassa seci bulunmaktadır.

“İşâret itdi men fakîr-i za'îfe, nahif-i lehîfe” (Kaplan, 2015, s. 47)

“Hazret-i şeri'at-şi'âr, tarîkat-disâr, hakîkat-âsâr, mihr-i burc-1 ma' rifetden; mühr-i dürc-i meskenetden.” (Ateş, 2017, s. 24)

Bu bakımdan; İlâhî’nin şerhlerinin mensur kısımlarında en fazla mutarraf seciyi, daha sonra mütevâzî seciyi kullandığını, yer yer de murassa seciden faydalandığını söylemek mümkündür.

İlâhî eserlerinin mensur kısımlarında sadece seciden yararlanmamıştır. Secininin yanında cinâs sanatından da faydalanmıştır. Eserlerinde hem tam hem de tam olmayan cinâs örneklerini görmek mümkündür. Örneğin; R̂ิşent̂-nâme' den alıntıladığımız yukarıdaki metinde "yüzini”" kelimelerinde hem "çehre" hem de "taraf" anlamı kullanıldığından tam cinâs; "açılmasasaçılmasa" ve "lâyık-ayık" kelimelerinde tam olmayan cinâs görülmektedir. Müşkil- 
güşấ dan alıntılanan aşağıdaki metinlerde ise "kalb" hem "yürek" hem de "sahte" anlamıyla kullanıldığından ve "bâm" hem "çatı" hem de "sabah vakti" anlamında kullanıldığından bu kelimelerde tam cinâs; "lâzımdur-mülâzımdur" kelimelerinde tam olmayan cinâs vardır.

“Ve bu ma’nî sülûk makâmında mukîm olana lâzımdur, çün hidmetde rûz u şeb mülâzımdur” (Ateş, 2017, s. 97).

“Sûfîyüz didi ya’nî kudûret-i cismâniyyeden sâfuz ve kalb eger kalb olsa 'ayn-1

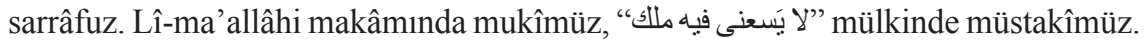
Zîr ü bâlâdan fârigüz, bizden isteme bâmı nûr-1 '1şka gark olan ne bilür şâm ü bâmı" (Ateş, 2017, s. 98).

İlâhî'nin her iki eserinde de kullandığı diğer bir sanat ise tezattır. Aşağıdaki alıntılarda R̂ิşentnâme' deki "subh-şâm", "küfr-İslâm", "lutf-kahr", "kabz-bast", "celâl-cemâl”, "gayb-şuhûd” kelimeleri ve Müşkil-güşấ daki "küfr-din”, “cehennem-cennet”, "rahat-mihnet” kelimeleri bir arada kullanılarak tezat sanatından faydalanmıştır.

"Murâd subh [u] şâmdan küfr [ü] İslâm ola yâ lutf u kahr yâ kabz u bast yâ tecellî-i celâl u cemâl yâ 'âlem-i gayb u şuhûd”' (Kaplan, 2015, s. 29).

“Küfr-ile dîn, iki 'âlemdür yakîn; biri cehennemdür, biri cennet, biri râhatdur ve biri mihnet” (Ateş, 2017, s. 49).

İlâhî’nin eserlerinde kullandığı başka bir sanat da iştikaktır. Aynı kökten türeyen kelimeleri

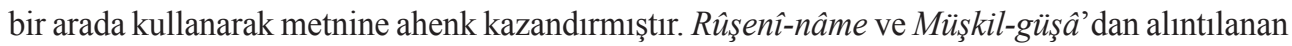
aşağıdaki kısımlarda "sayd-sayyâd”, "irşâd-mürşid"; "müstecmi'-cemî', "hamd-mahmûd”, 'abd-ma'bûd” kelimeleri ile iştikak sanatı yapılmıştır.

"Murâd "sayd"dan halâyık ola mürşid-i sâhib-i irşâd oları sayd eyler ve sayyâd-1 hakîkî Hak te’âlâdur.” (Kaplan, 2015, s. 64).

'Yâ'nî çün kim mü'min cidd ü cehd-ile ol ezelî 'ahd-ile kendüzin müstecmi'-i cemî'-i 'ulûm-1 İlâhî tapdı ve kalbinde beytu'llâhı tapdı. Hamd itse Mahmûd'ına ve 'abd olsa ma'bûdına, makbûl düşer eyyün min-kavlin ana kim bu menkûl ma'kûl düşer” (Ateş, 2017, s. 70).

Sonuç olarak; İlâhî eserlerinin mensur kısımlarında yoğunluklu olarak iktibas, telmih, seci ve cinâslardan faydalanmasının yanı sıra tezat ve iştikak sanatlarından da yararlanmıştır. Bu sanatlara ek olarak, Ateş çalışmasında (2017) İlâhî’nin Müşkil-güşâ adlı eserinde akis sanatından da faydalandığını belirterek şu örnekleri verir:

“Müşkilāt-1 ebyātını, ebyātınun müşkilātını hall ideler" (Ateş, 2017, s. 15).

"tecellî̀-yi celāl-i cemālinden hâlî degül ve tecelli-yi cemāl-i celālinden. Nîşinde nūş1 var ve nūşında nîş, kışında yazı var ve yazında kış.” (Ateş, 2017, s. 16). 


\section{4. İlâhî’nin Şairliği}

İlâhî, hem Rûşen̂̀-nâme'de hem de Müşkil-güşấ' da ele aldığı beyitleri mensur şekilde açıkladıktan sonra onları bir de manzum olarak açıklama yoluna gitmiştir. Bu sayede aslında bir de manzum bir şerh ortaya koyarak şârihliğinin yanı sıra şairlik yönünü de okurlarına göstermiştir. İlâhî’nin bu çabası, muhtemelen şairliğini ispat için değil, mensur yazılmış metindeki tekdüzeliği kırmak amacıyladır. Ya da anlatacaklarını daha etkili aktarabilmek için şiir dilinin akıcılığını ve akılda kalıcılığını kullanmak istemiş olabilir. Sebebi her ne olursa olsun, sonuç olarak; kaynaklarda kendisi ve şairlik kimliğine dair bilgiye ulaşamadığımız İlâhî'nin elimizde bir mesnevi oluşturacak hacimde beyitleri mevcuttur. ${ }^{11}$

İlâhî'nin R̂uşenî-nâme adlı eserinde 290 adet ve Müşkil-güşâ adlı eserinde 340 (Ateş, 2017, s. 17) adet olmak üzere elimizde toplamda 630 adet beyti bulunmaktadır. Bu beyitlerin tamamı kendi arasında kafiyeli olarak mesnevi nazım şekliyle aruzun kısa kalıpları ile kaleme alınmıştır. R̂şsent̂-nâme' de bulunan 30 şiir parçasının 10 tanesinde "Fâilâtün Fâilâtün Fâilün" ve 10 tanesinde "Mefâîlün Mefâilün Feûlün"; Müşkil-güşấ da 30 şiir parçasında "Feilâtün Mefâilün Feilün” (Ateş, 2017, s. 18) vezinleri kullanılmıştır. Bu vezinler onun en sık kullandığı vezinlerdir. Vezinleri kullanırken yer yer vasl, med ve imâle kullanımlarının olduğu, aşırı sık olmasa da zihaf kusurunu işlediği ancak genel itibariyle başarılı bir şair olduğu söylenebilir. Kafiye açısından bakıldığında ise farklı kafiye türlerini kullanabildiği ve göze batan bir kafiye kusurunun olmadığı öne sürülebilir. Aşağıdaki beyitlerde de görüleceği üzere kısa vezin kalıpları ile ya da farklı türdeki kafiyelerin kullanımı ile akıcı, kulağa hoş gelen, didaktik bir şiir dili oluşturulmuştur.

"Ey haste gönül işit bu pendi

Dermâna yetür bu derd-mendi

Pendim bu durur sana ki dâ'im

Her subh uyag ol olma nâ'im

Gafletde giçürme rûzigârı

Fevt eyleme leyl ile nehârı” (Kaplan, 2015, s. 49)

“"Arş u kürsî disen yaraşur ana

Rûh-1 kudsî disen yaraşur ana

Sirr-1 esrâra kâbil ola o dil

Nice şerh ide ol rumûzı bu dil

Ol dil âyîne-i İlâhî'dür

Mahzen-i genc-i pâdişâhîdür" (Ateş, 2017, s. 31)

11 Ateş çalışmasında İlâhî’nin şairliğgini değerlendirir. İlâhî’nin teknik açıdan usta bir şair olduğunu, tartışmalı birkaç beyit dışında kafiye hatası tespit edilemediğini, şiirine nasihatçi ve açıklayıcı/anlatıcı üslupların hâkim olduğunu belirterek şiirlerinden örneklerle bu görüşlerini destekler (Ateş, 2017, s. 17-20). 
İlâhî, kullandığı bu şiir dilini oluştururken aynı zamanda çeşitli söz sanatlarından da faydalanmıştır. Bu bakımdan İlâhî’nin zorlanmadan kullandığı söz sanatlarından birinin iktibas olduğu söylenebilir. Metnin anlam bütünlüğüne katkı sağlayacak biçimde ayet ve hadisleri şiirlerinde gerekli gördüğü yerlere yerleştirmiştir. Aşağıdaki beyitlerde İnsan suresinin "Rableri onlara içirecektir." anlamına gelen 21. ayet-i kerimesi iktibas edilmiştir.

“Sekâhüm Rabbühümden mest olardur

Hakîkat nîstîde hestî olardur” (Kaplan, 2015, s. 52)

“Anun âhı müdâm olur müdâmî

Sekâhüm Rabbühümdendür müdâmı” (Ateş, 2017, s. 43)

İlâhî’nin şiirlerinde iktibasın yanı sıra çeşitli telmihler görmek de mümkündür. İlâhî, telmihler vasıtasıyla metninin çağrıştırdığı anlam alanını genişletmiştir:

“Geh kehfüz ü gâh içinde yatan

Geh Yûsuf u gâh anı satan” (Kaplan, 2015, s. 73)

"Anun îmân ola dâ’im yemîni

Mesîhâ-tek tapa ol Meryemini” (Ateş, 2017, s. 27)

R̂ิşenî-nâme' den alınan ilk beyitte "Kehf" ve "yatan" kelimeleri ile bir mağarada yıllarca uyuyup daha sonra uyandırılan Ashab-1 Kehf'e, "Yûsuf” ile Hazret-i Yûsuf kıssasına ve "satan" ile abilerinin onu satma hadisesine telmih yapılmıştır. Müşkil-güşâ' dan alınan beyitte ise "Mesîhâ" kelimesi ile Hazret-i İsâ'ya ve "Meryem" kelimesi ile de onun annesi olan Hazret-i Meryem'e telmihte bulunulmuştur.

Her şair gibi İlâhî de şiirlerinde teşbih ve istiarelere bol bol yer vermiştir. Yukarıdaki beyitlerde kendini Ashab-1 Kehf'e, Hazret-i Yûsuf'a ya da Hazret-i Meryem'ini bulan Hazret-i İsâ'ya benzetmesi buna örnek verilebilir.

İlâhî’nin kullandığı bir diğer sanat ise tezattır. İlâhî şiirlerinde öğüt vermeyi hedeflediğinden karşıtlıkları bir arada vererek okuruna yol göstermektedir. Aşağıdaki beyitlerde "yohlug-varlıg” ve "leyl-nehâr" kelimeleri ile zitlıklar oluşturulmuştur:

"Fakr yohlugdur kamudan bil

Varlıgı terk it ol Hakk'a kâbil” (Ateş, 2017, s. 33)

"Gafletde giçürme rûzigârı

Fevt eyleme leyl ile nehârı” (Kaplan, 2015, s. 49)

"Ne bilsünler nedür subh ile şâmı

Ne bilsünler ne yirdür Misr u Şâm'ı” (Ateş, 2017, s. 100)

Eserlerinin mensur kısımlarında cinâsı kullanan İlâhî şiirlerinde de cinâs sanatından

12 Metindeki Arapça ifade tarafımızdan latinize edilmiştir. 
faydalanmıştır. Yukarıdaki örneklerde “yemîni/ Meryemini”, "bil-kâbil” ve "şâmı-Şâm'ı” kelimeleri arasında cinâs bulunmaktadır.

"Sâbit-kadem ol şerî’at içre

Sâhib-kerem ol tarîkat içre” (Kaplan, 2015, s. 49)

"Bu mesâlikde sâlik olanlar

Bu memâlikde mâlik olanlar” (Ateş, 2017, s. 101)

İlâhî yukarıdaki örnek beyitlerde de görüleceği gibi bazı beyitleri ölçü, sayı ve kafiye bakımından birbirine eşit yazarak tarsi' sanatından faydalanmıştır. Bu sayede metnine ses bakımından bir ahenk kazandırmıştır.

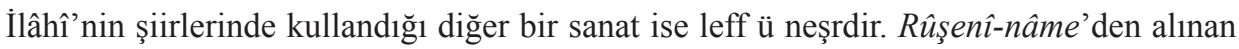
aşağıdaki beyitte, üst mısrada bulunan "Leylâ" alt misrada "fitne" kelimesi ile; yine üst misrada bulunan "Mecnûn” alt mısrada bulunan "meftun” kelimesi ile karşılanmıştır. Müşkil-güş̧â' dan alınan beyitte ise üst mısradaki "kırtâs-1 rûz" kelime grubu alt mısrada bulunan "nûr" kelimesi ile yine üst misrada bulunan "hatt-1 şeb" kelime grubu da alt mısrada bulunan "duhân" kelimesi ile karşılanmıştır.

“Gönüldür gâh Leylâ gâh Mecnûn

Gönüldür gâh fitne gâh meftûn” (Kaplan, 2015, s. 87)

"Yüri kirtâs-1 rûza hatt-1 şeb çek

Budur söyle duhân u nûr gerçek” (Ateş, 2017, s. 25)

İlâhî şiirlerinde çok sık olmasa da iade sanatına da başvurmuştur. R̂ิş̧ent̂-nâme' den alınan aşağıdaki beytin ilk mısraı "müsterâh" kelimesi ile bitirilmiş ve ikinci mısra yine aynı kelime ile başlatılmıştır. Müşkil-güşấ' dan alınan beyitte ise ilk mısra "salâtı" ile bitirilerek diğer mısra yine aynı kelime ile başlatılmıştır.

"Mest-i râh ol olma ey cân müsterâh

Müsterâh olan ne bilsün rîh-i râh" (Kaplan, 2015, s. 80)

"Bilürler kim nedür savm u salâtı

Salâtı olmayan bulamaz necâtı” (Ateş, 2017, s. 99)

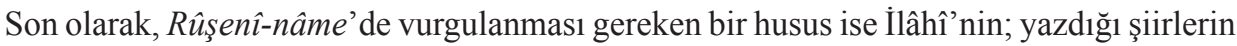
bölümlerini, birebir olmasa da bir mesnevi usulüyle tanzim etmesidir. Eserine giriş yapıp sebeb-i telif kısmına da değinen İlâhî daha sonra şerh edeceği şiirin tamamını verir ve okuruna nasihatte bulunur. Ardından Rûşenî'den himmet ister ve "Münacaat" başlı̆̆ı atarak Allah'a yalvardığı bir şiir kaleme alır. Hemen ardından da ilk beyti vererek açıklamalarına başlar. Son beyti açıklamasıyla beraber "Hâtime" başlığı atar, mahlasını verir. Daha sonra, eserinin adını ve tamamladığı tarihi de vererek "Nazm-1 Türk̂̂” başlığı ile dua ettiği bir şiir kaleme alarak eserini nihayetlendirir. 
Netice itibariyle, İlâhî’nin şiirlerinde umumiyetle kullandığı dilin akıcı ve anlaşılır olduğu, temel gayesinin bir şerh metni oluşturmak olması hasebiyle öğütleyici ve açıklayıcı bir dil kullandığ 1 söylenebilir. Bu dili oluştururken de iktibas, telmih, teşbih, istiare, tezat, cinâs, tarsi', leff ü neşr ve iade sanatlarından yararlandığı ve teknik açıdan başarılı bir şair olduğu öne sürülebilir.

\section{SONUÇ}

15. yüzyıl Anadolu sahası şerh edebiyatı alanında İlâhî mahlasını kullanan Abdullah İlâhî ve Ahmed İlâhî dışında başka bir İlâhî daha bulunmaktadır. Söz konusu İlâhî hakkında kaynaklarda herhangi bir bilgiye ulaşılamamıştır. Bu sebeple, onun diğer İlâhî'lerden farklı biri olup olmadığını anlayabilmek için öncelikle diğer İlâhî’lerin hayatlarına ve eserlerine bakılmıştır. Diğerlerinin Nakşî olması ve kaynaklarda onlara atfedilen eserler arasında R̂ิşentnâme ve Müşkil-güşâ adlı eserlerin bulunmaması, bu İlâhî'nin onlardan farklı biri olduğunu düşündürmüştür.

Farklı biri olduğuna kanaat edilen İlâhî’nin hayatı hakkında bilgi bulabilmek amacıyla eserlerine müracaat edilmiştir. İlâhî’nin R̂̂şen̂̀-nâme'sinde Dede Ömer Rûşenî için kullandığ çeşitli ifadelerin bulunması ve eserin adının R̂ûsent̂-nâme olması, onun Rûşenî’ye bağlı bir mürit olduğunu ya da Dede Ömer'in sıkı bir takipçisi olduğunu düşündürmüştür. Genel itibariyle o dönem eserlerinde, bağlı bulunduğu şeyhin dışındaki bir şeyhe övücü ifadeler kullanılmasının pek sık rastlanan bir durum olmaması bu İlâhî’nin Rûşenî tarikatına bağlı olabileceğini akla getirmiştir.

Bunlara ek olarak, Rûşent-nâme ve Müşkil-güşâ adlı eserlerde kullanılan şerh metodunun çalışmamızda ortaya konulmaya çalışıldığı üzere benzerlikler taşıdığı görülmüştür. Şârîhin her iki eserinde de ortak olarak seci, cinâs, iştikak ve tezat sanatlarına başvurduğu görülmüştür. $\mathrm{Bu}$ sanatlara ek olarak beyitleri açıklarken kullanılan üslubun ve mensur bir şerhe manzum bir şerh eklenmesi yönteminin her iki eserde de benzer bir biçimde kullanılması bu iki eserin aynı kişiye ait olduğu sonucunu doğurmuştur.

Dede Ömer Rûşenî’nin şiirlerini şerh ederken nesre ek olarak nazma başvuran İlâhî, şârihliğinin yanında aynı zamanda bir şairdir. Mesnevi nazım biçimi ve kafiye sistemi ile yazdığı yüzlerce beyti elimizde bulunan İlâhî teknik açıdan başarılı sayılabilecek şairlerdendir. Okuruna bir şeyler öğretme derdi bulunan şair, şiirlerini kaleme alırken iktibas, telmih, teşbih, istiare, tezat, cinâs, tarsi', leff ü neşr ve iade gibi edebi sanatlardan faydalanmıştır.

Sonuç olarak, İlâhî 15. yüzyılda yaşamış şair bir şârihtir. Yazdıklarından hareketle Dede Ömer Rûşenî’ye gönülden bağlı ya da onun sıkı bir takipçisi olduğunu düşündüren İlâhî’nin elimizde iki eseri mevcuttur. Bunlardan biri Ŗ̂şent̂-nâme diğeri ise Müşkil-güşấ'dır. Elimizdeki bilgilere göre her ikisi de Anadolu sahasındaki ilk Türkçe şiir şerhleridir ve İlâhî de ilk Türkçe şiir şârihidir. 
Hakem Değerlendirmesi: Dış bağımsız.

Çıkar Çatışması: Yazar çıkar çatışması bildirmemiştir.

Finansal Destek: Yazar bu çalışma için finansal destek almadığını beyan etmiştir.

Peer-review: Externally peer-reviewed.

Conflict of Interest: The author has no conflict of interest to declare.

Grant Support: The author declared that this study has received no financial support.

\section{KAYNAKÇA/REFERENCES}

Ateş, C. (2017). Dede Ömer Rûşen̂̂’nin Bir Şiirinin Şerhi: Müşkil-Güşâ (Metin-Inceleme). (Yüksek Lisans Tezi). Karadeniz Teknik Üniversitesi Sosyal Bilimler Enstitüsü, Trabzon.

Ceylan, Ö. (2007). Tasavvufi Şiir Şerhleri. İstanbul: Kapı Yayınları.

İlâhî, M. A. (2015). Tasavvuf-nâme. (M. Kaçar, \& A. Akdağ, Haz.) İstanbul: Büyüyenay Yayınları.

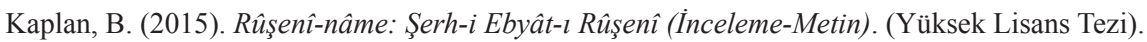

İstanbul Üniversitesi Sosyal Bilimler Enstitüsü, İstanbul.

Kara, M. (1988). Molla İlâhî’ye Dair. Osmanlı Araştırmaları(VII-VIII), 365-392.

Kara, M., \& Algar, H. (1988). Abdullah-1 İlâhî . Türkiye Diyanet Vakfi Íslam Ansiklopedisi (Cilt 1, s. 110112). içinde İstanbul: Türkiye Diyanet Vakfı. Eylül 2020 tarihinde https://islamansiklopedisi.org.tr/ abdullah-i-ilahi adresinden alındı

Kur'an-ı Kerim. (2020, Eylül). Diyanet İşleri Başkanlığı Kur'an-1 Kerim: https://kuran.diyanet.gov.tr/ mushaf/kuran-meal-1/insan-suresi-76/ayet-21/diyanet-isleri-baskanligi-meali-1 adresinden alınd1

Kurnaz, C. (1996). Ahmed İlâhî’nin Türkçe Şiirleri. ILAM Araştırma Dergisi, 1(1), s. 169-189.

Kuru, E. (2014). Şeyh Ahmed İlâhî ve Pend-nâme'si. Turkish Studies - International Periodical For The Languages, Literature and History of Turkish or Turkic, 9(9), s. 771-784.

Ördek, Ş. (2020, Eylül). Şeyh Ahmed İlâhî Efendi. Türk Edebiyatı İsimler Sözlüğü: http://teis.yesevi.edu. tr/madde-detay/ilahi-seyh-ahmed-ilahi-efendi adresinden alınd

Özçelik, Y. N. (1990). Abdullah İlâhî ve Meslekü 't-TâlibinVe'l-Vâsilî (Edisyon-Kritik). (Yüksek lisans Tezi). Gazi Üniversitesi Sosyal Bilimler Enstitüsü, Ankara.

Tavukçu, O. K. (2005). Dede Ömer Rûşenî: hayatı, eserleri, edebî kişiliği ve Dîvânı'nın tenkidli metni. Eylül 2020 tarihinde https://ekitap.ktb.gov.tr/TR-78365/dede-omer-ruseni-divani.html adresinden alındı

Tek, A. (2006). Molla [Ahmed] İlahî'nin Ayasofya Camii'nde Fatih'in Huzurunda Tasavvufa Dair Yaptığ1 Konuşmalar. Uludağ Üniversitesi İlahiyat Fakültesi Dergisi, 15(1), s. 285-305.

Uyan, Ö. (2016). Müşkil-güşâ (İnceleme-Açıklamalı Metin). İstanbul: Kitabevi Yayınları.

Vicdani, S. (1995). Tomar-1 Turuk-1 Aliyye. (İ. Gündüz, Haz.) İstanbul: Enderun Kitabevi.

Yıldırım, İ. (2014). Şeyh Ahmed İlâhî’nin Bilinmeyen Şiirleri ve Bu Şiirlerin Şekil ve Muhteva Husûsiyetleri. The Journal of Academic Social Science(5), s. 572-591. 